\title{
Monitoring of pathogen-specific T-cell immune reconstitution after allogeneic hematopoietic stem cell transplantation
}

\author{
Shigeo Fuji ${ }^{12}$, Markus Kapp ${ }^{1}$ and Hermann Einsele ${ }^{1 *}$ \\ 1 Department of Internal Medicine II, Division of Hematology, University Hospital of Würzburg, Würzburg, Germany \\ ${ }^{2}$ Division of Hematopoietic Stem Cell Transplantation, National Cancer Center Hospital, Tokyo, Japan
}

Edited by:

Antoine Toubert, Université Paris

Diderot, France

\section{Reviewed by:}

Attilio Bondanza, S. Raffaele Scientific Institute, Italy

Jean Villard, Geneva University

Hospital, Switzerland

\section{*Correspondence:}

Hermann Einsele, Department of Internal Medicine II, Division of Hematology, University Hospital of Würzburg, Josef-Schneider-Straße 2, 97080 Würzburg, Germany e-mail: Einsele_H@medizin. uni-wuerzburg.de

\begin{abstract}
The clinical outcome after allogeneic hematopoietic stem cell transplantation (HSCT) has been significantly improved during the last decades with regard to the reduction in organ failure, infection, and severe acute graft-versus-host disease. However, severe complications due to infectious diseases are still one of the major causes of morbidity and mortality after allogeneic HSCT, in particular in patients receiving haploidentical HSCT or cord blood transplant due to a slow and often incomplete immune reconstitution. In order to improve the immune control of pathogens without an increased risk of alloreactivity, adoptive immunotherapy using highly enriched pathogen-specific $T$ cells offers a promising approach. In order to identify patients who are at high risk for infectious diseases, several monitoring assays have been developed with potential for the guidance of immunosuppressive drugs and adoptive immunotherapy in clinical practice. In this article, we aim to give a comprehensive overview regarding current developments of T-cell monitoring techniques focusing on T cells against viruses and fungi. In particular, we will focus on rather simple, fast, non-labor-intensive, cellular assays which could be integrated in routine clinical screening approaches.
\end{abstract}

Keywords: virus, fungi, $\mathrm{T}$ cell, immune reconstitution, allogeneic stem cell transplantation

\section{INTRODUCTION}

The clinical outcome after allogeneic hematopoietic stem cell transplantation (HSCT) has been significantly improved during the last decades with regard to the reduction in organ failure, infection, and severe acute graft-versus-host disease (GVHD). These advances have rendered allogeneic HSCT to an integral part of treatment for hematological malignancies $(1,2)$. However, severe complications due to infectious diseases are still one of the major causes of morbidity and mortality after allogeneic HSCT, in particular in patients receiving haploidentical HSCT or cord blood transplant due to a slow and often incomplete immune reconstitution. The reduction of immunosuppressive drugs could pave the way to strengthen Tcell responses against pathogens after allogeneic HSCT. However, blind rapid tapering or cessation of immunosuppressive drugs is associated with an increased risk of alloreaction with subsequent clinical consequences such as increase of severe acute or chronic GVHD as demonstrated previously $(3,4)$. In order to improve the immune control of pathogens without an increased risk of alloreactivity, adoptive immunotherapy using highly enriched pathogen-specific $\mathrm{T}$ cells offers a promising approach. Adoptive immunotherapy against several pathogens has been already evaluated within clinical trials as reviewed previously (5).

In order to identify patients who are at high risk for infectious diseases, several monitoring assays have been developed with potential for the guidance of immunosuppressive drugs and adoptive immunotherapy in clinical practice. In this article, we aim to give a comprehensive overview regarding current developments of T-cell monitoring techniques focusing on $\mathrm{T}$ cells against viruses and fungi. In particular, we will focus on rather simple, fast, non-labor-intensive, cellular assays which could be integrated in routine clinical screening approaches.

\section{THE ROLE OF PATHOGEN-SPECIFIC IMMUNITY IN PREVENTION AND CONTROL OF INFECTIOUS DISEASES VIRUS-SPECIFIC T-CELL IMMUNITY}

It is well-known that virus-specific $\mathrm{T}$ cells are important to prevent and/or control viral infection after allogeneic HSCT. Cytomegalovirus (CMV) is one of the most intensively investigated targets of immunotherapy after allogeneic HSCT (6). After allogeneic HSCT, the first emergence of CMV reactive antigenemia triggers the expansion of donor-derived CMV-specific T cells. These expanded cells usually have a phenotype of effectoror effector-memory type. The presence of CMV-specific T cells in patients after allogeneic HSCT was reported to be protective against the recurrence of CMV antigenemia (7-12). Especially, CMV seropositive patients with profound immunosuppression or CMV seropositive patients who received stem cells from a CMV-seronegative donor are at high risk for a significant delay in reconstitution of functional CMV-specific T cell which is associated with persistent CMV viremia and a higher risk of CMV disease (8-12). Furthermore, adoptive T-cell therapy 
of CMV-specific T cells was demonstrated to be effective for the prophylaxis and treatment of CMV disease after allogeneic HSCT $(13,14)$.

The importance of virus-specific T cells has been also demonstrated with regard to other viruses such as adenovirus (15-18), EB virus (19-21), BK virus (22-25), and JC virus (26, 27). Recently, banked third party virus-specific $T$ cells were reported to be safe and effective for the treatment of viral disease after allogeneic HSCT, which circumvents a major obstacle to the wider use of virus-specific $\mathrm{T}$ cells, in particular in patients after cord blood transplant (28).

The monitoring of T-cell immunity against these viruses can be useful to assess the risk of viral infections. The benefit of adoptive T-cell therapy as prophylaxis or as treatment should be ideally assessed in prospective clinical trials.

\section{FUNGUS-SPECIFIC T-CELL IMMUNITY}

For a long time fungus-specific $\mathrm{T}$ cells have not been regarded as important to control fungal diseases. However, there is growing evidence that $\mathrm{CD}^{+} \mathrm{T}$ cells provide defense mechanisms against fungal infection (29-32). The majority of patients diagnosed with invasive aspergillosis after allogeneic HSCT are not neutropenic which for a long time was considered the only or at least the most important immune mechanism to prevent fungal disease $(33,34)$. Recent studies have shown that fungus-specific $\mathrm{T}$ cells are detectable in healthy individuals and patients with hematological malignancies $(29,32,35)$. Due to the paucity of clinical studies which assessed the impact of presence of fungus-specific T cells compared to virus-specific T cells, further prospective studies which assess the importance of fungus-specific $\mathrm{T}$ cells on preventing/controlling fungal infection are urgently needed.

In addition, the improved outcome of invasive Aspergillus following adoptive T-cell therapy for invasive Aspergillosis demonstrates the clinical value of transfer of fungus-specific $T$ cells from the stem cell donor (36). Furthermore, recent reports showed that the GMP-grade-Aspergillus-specific T cells could be produced for clinical trials using commercially available enrichment protocols (37-40).

\section{HOW CAN PATHOGEN-SPECIFIC IMMUNITY BE MONITORED?}

Up to date, various methods are available to assess T-cell immunity against specific antigens. However, some methods like limitingdilution assays are not feasible due to the labor-intensive works which cannot be a part of routine clinical practice. Here we summarize three simple broadly available methods which can be performed using peripheral blood mononuclear cells (PBMC) or whole blood without long-term ex vivo culture, and using commercially available reagents. In addition, PBMC can be frozen without the loss of the function when tested in intracellular cytokine staining (ICS) or Enzyme-linked immunosorbent spot (ELISPOT), which is practically very important with regard to reproducibility and standardization with strict quality control (41). Combinations of these assays are needed for the confirmation of results and comprehensive measurement of different T-cell functions. The advantages and disadvantages of each method are summarized in Table 1.

\section{ENZYME-LINKED IMMUNOSORBENT SPOT}

Enzyme-linked immunosorbent spot is one of the most established methods to detect functional immunity (42-44). In brief, PBMC are cultured for $18-24 \mathrm{~h}$ on an anticytokine capture antibodycoated membrane in the presence of an antigen. Following culture, each antigen-specific $\mathrm{T}$ cells will release cytokines that will bind to the capture antibody on the membrane. The cells are then washed and the secreted cytokines can be detected on the membrane by use of an enzymatically labeled antibody and insoluble chromogenic substrate. In this assay, frequencies of cytokine-secreting $\mathrm{T}$ cells can be counted after in vitro stimulation of PBMC by defined antigens/peptides without previous ex vivo expansion. In addition, ELISPOT assays allow the size and intensity of the spots to be calculated, which correlated with the amount of cytokines secreted by each cell. As shown in Figure 1A, we are able to detect the induction of IFN- $\gamma$ after the stimulation with CMV pp65 IE-derived peptides in patients after allogeneic HSCT.

Enzyme-linked immunosorbent spot offers several advantages: (1) many samples can be tested simultaneously using one plate; (2) the secretion of cytokines can be assessed in contrast to the

Table 1 | Comparison of three T-cell assays.

\begin{tabular}{|c|c|c|}
\hline Assay & Advantage & Disadvantage \\
\hline ELISPOT & $\begin{array}{l}\text { No cell fixation } \\
\text { The same cells can be retested } \\
\text { Suitable to test many samples simultaneously } \\
\text { Cytotoxicity assay can be induced } \\
\text { A lower number of cells required for analysis }\end{array}$ & $\begin{array}{l}\text { Cell of origin of cytokine production unclear } \\
\text { No sorting of cytokine-secreting cells possible }\end{array}$ \\
\hline $\begin{array}{l}\text { Intracellular cytokine } \\
\text { staining }\end{array}$ & $\begin{array}{l}\text { Assessment of multiple cytokines at single cell level } \\
\text { Combination with phenotyping and cytotoxicity assay }\end{array}$ & $\begin{array}{l}\text { Cells have to be fixated and permeabilized } \\
\text { No sorting of vital cell populations possible }\end{array}$ \\
\hline MHC-multimer staining & $\begin{array}{l}\text { Combination with phenotyping } \\
\text { Sorting of antigen-specific T cells, which can be used for } \\
\text { adoptive T-cell therapy } \\
\text { Detection of dysfunction/non-functional antigen-specific } \\
\text { T cells, e.g., naïve T cells }\end{array}$ & $\begin{array}{l}\text { Each tetramer has to be produced for respective HLA } \\
\text { typing and peptide } \\
\text { Not suitable for the assessment of cytokine secretion } \\
\text { (functionality) }\end{array}$ \\
\hline
\end{tabular}




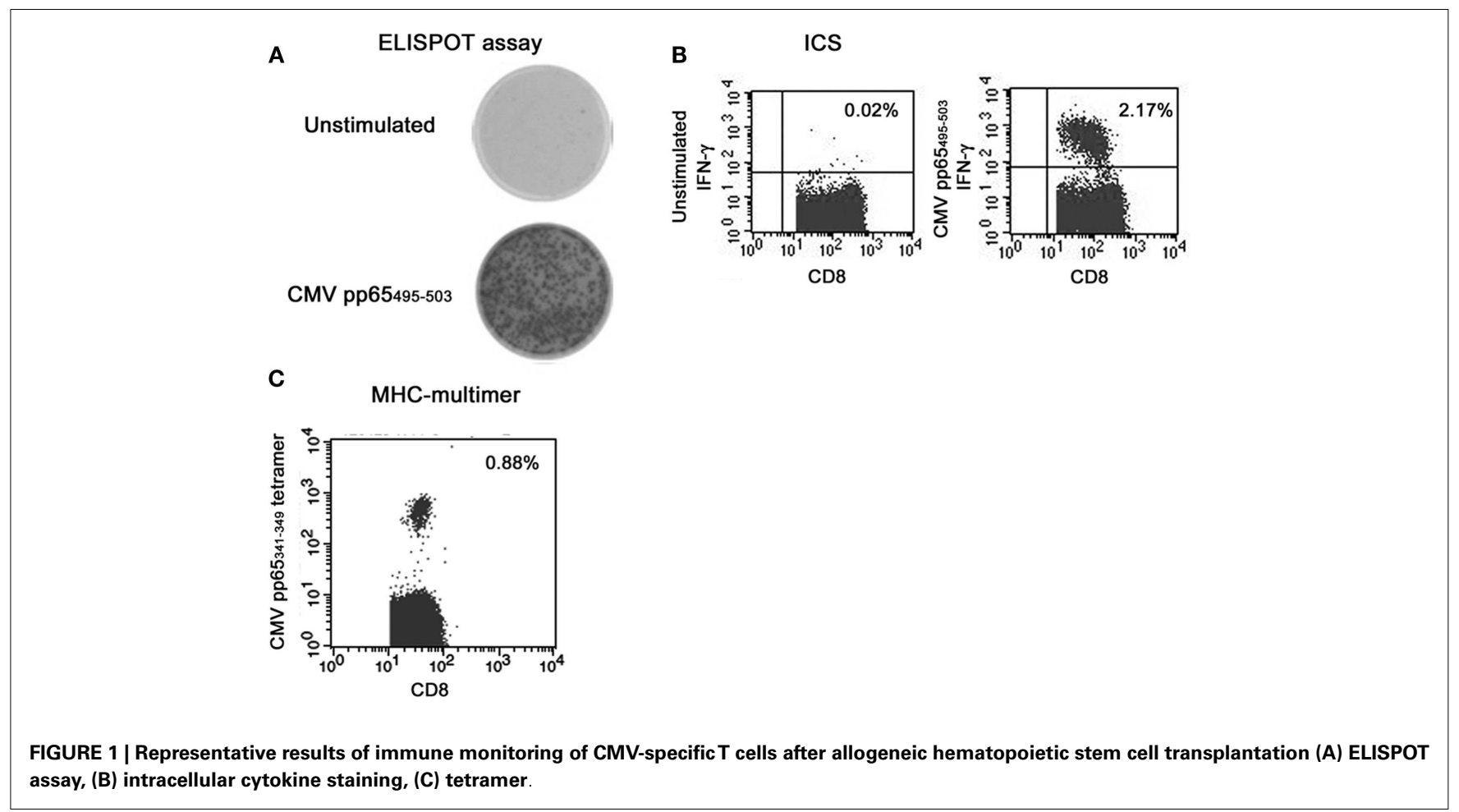

artificially retained cytokines in ICS; (3) the cell numbers can be downscaled per well in comparison to flow cytometry-based methods.

Cytotoxic activity can be assessed using granzyme B ELISPOT. Granzyme B ELISPOT has been reported to have excellent correlation with the ${ }^{51} \mathrm{Cr}$-release assay for measuring cytotoxic activity of T cells $(45,46)$. Furthermore, multiple-color fluorospot assays make the analysis of single cells secreting several cytokines possible $(47,48)$. Detecting each cytokine with a different fluorophore, polyfunctionality of $\mathrm{T}$ cells can be analyzed, suggested to be important to protect against various infectious diseases.

The disadvantages of ELISPOT are: (1) it is difficult to determine which immune cells secrete IFN- $\gamma$. This is critical to assess the immune status after allogeneic HSCT. As Wang and Colleagues reported, the response to 9-mer peptide, which is expected to induce cytokines in an HLA class I-restricted, can also be HLA class II-restricted $(49,50)$. Therefore, when IFN- $\gamma$ induction in ELISPOT assay is detected using stimulation with lengths of peptides including peptide-pool, cell of origin of IFN$\gamma$ secretion has to be determined using CD4/CD8 depletion or HLA blocking assays; (2) sorting of cytokine-secreting cells is impossible.

\section{INTRACELLULAR CYTOKINE STAINING}

Intracellular cytokine staining is also one of the most established methods to detect functional immunity $(51,52)$. In brief, PBMC are cultured for $6-18 \mathrm{~h}$ in the presence of an antigen. To preserve the generated cytokines within the cytoplasm, a Golgiblocking agent (e.g., Brefeldin A or Momensin) is added during the stimulation. After the stimulation, samples are collected, fixated and permeabilized. Consecutively, antibodies against intracellular cytokines are added. When surface markers whose binding is sensitive to fixation and permeabilization are stained in combination with ICS, they should be stained before fixation and permeabilization. Stained cells were analyzed using a flow cytometer. A representative result is shown in Figure 1B.

The advantages of ICS are as follows: (1) the phenotype of each cell which secretes the cytokine can be determined (53); (2) the cytolytic potential of the target cells can be assessed using CD107a degranulation assay in combination with the assessment of multiple cytokine induction.

The disadvantages of ICS are: (1) reagents such as Brefeldin A are required to retain cytokines in the cytoplasm; (2) the cells have to be permeabilized prior to the staining of the cells with antibodies against the cytokines, which makes it impossible to expand the sorted T cells.

\section{MHC-MULTIMER STAINING}

MHC-multimers are synthetic structures made from HLA molecules linked together to form a multimeric complex which are loaded with antigen-specific peptide. Cells stained with multimer and antibodies against surface markers can be analyzed using a flow cytometry. The fluorescence intensity using the tetramer loaded with a high-avidity peptide derived from virus is usually high enough to discriminate the positive population in contrast to the result using the tetramer loaded with a low-avidity peptide derived from autologous antigen (54). A representative result is shown in Figure 1C.

The advantages of multimer assays are as follows: (1) combined analysis of phenotyping and specificity can be performed using the antibodies against surface markers. MHC-multimer can detect T cells which do not secrete cytokines, for instance naïve T cells. In 
combination with the phenotyping and MHC-multimer staining, we can assess the frequency of all antigen-specific $\mathrm{T}$ cells including dysfunctional/non-functional; (2) antigen-specific T cells can be sorted with a high purity. For this purpose, the streptamer technology is demonstrated to be useful $(54,55)$. Sorted cells can be used for adoptive T-cell therapy as a GMP-grade agent without regulatory issues (55).

The disadvantages of multimer staining are: (1) the multimer is not able to assess the functional status of antigenspecific $\mathrm{T}$ cells simultaneously. There can be a discrepancy in the frequency of antigen-specific $\mathrm{T}$ cells detected by multimer and by ELISPOT/ICS. Several papers reported that T cells detected by ICS were more important than those detected by multimer to control infectious diseases as demonstrated in the study of CMV infection (56-58). Multimer assays can be combined with functional assays, but it is well-known that the stimulation with a respective peptide leads to loss of multimer staining due to the downregulation of $\mathrm{T}$-cell

\section{REFERENCES}

1. Gooley TA, Chien JW, Pergam SA, Hingorani S, Sorror ML, Boeckh M, et al. Reduced mortality after allogeneic hematopoieticcell transplantation. $N$ Engl $J$ Med (2010) 363:2091-101. doi:10. 1056/NEJMoa1004383

2. Horan JT, Logan BR, AgoviJohnson MA, Lazarus HM, Bacigalupo AA, Ballen KK, et al. Reducing the risk for transplantationrelated mortality after allogeneic hematopoietic cell transplantation: how much progress has been made? J Clin Oncol (2011) 29:805-13. doi:10.1200/JCO.2010. 32.5001

3. Ekberg H, Grinyó J, Nashan B, Vanrenterghem Y, Vincenti F, Voulgari A, et al. Cyclosporine sparing with mycophenolate mofetil, daclizumab and corticosteroids in renal allograft recipients: the CAESAR Study. Am J Transplant (2007) 7:560-70. doi:10.1111/j. 1600-6143.2006.01645.x

4. Hori A, Kami M, Ohnishi M, Murashige N, Kojima R, Takaue Y. Feasibility of early tapering of cyclosporine following reducedintensity stem cell transplantation for advanced hematologic or solid malignancies. Haematologica (2005) 90:1001-3.

5. Fuji S, Kapp M, Grigoleit GU, Einsele H. Adoptive immunotherapy with virus-specific $\mathrm{T}$ cells. Best Pract Res Clin Haematol (2011) 24:413-9. doi:10.1016/j. beha.2011.06.003

6. Ljungman P, Hakki M, Boeckh M. Cytomegalovirus in hematopoietic stem cell transplant recipients. Infect Dis Clin North Am (2010)
24:319-37. doi:10.1016/j.idc.2010. 01.008

7. Lilleri D, Gerna G, Fornara C, Lozza L, Maccario R, Locatelli F. Prospective simultaneous quantification of human cytomegalovirus-specific CD4+ and CD8+ T-cell reconstitution in young recipients of allogeneic hematopoietic stem cell transplants. Blood (2006) 108:1406-12. doi:10.1182/blood-2005-11012864

8. Lilleri D, Fornara C, Chiesa A, Caldera D, Alessandrino EP, Gerna G. Human cytomegalovirusspecific CD4+ and CD8+ T-cell reconstitution in adult allogeneic hematopoietic stem cell transplant recipients and immune control of viral infection. Haematologica (2008) 93:248-56. doi:10.3324/haematol.11912

9. Gratama JW, Brooimans RA, van der Holt B, Sintnicolaas K, van Doornum G, Niesters HG, et al. Monitoring cytomegalovirus IE-1 and pp65-specific CD4+ and CD8+ T-cell responses after allogeneic stem cell transplantation may identify patients at risk for recurrent CMV reactivations. Cytometry B Clin Cytom (2008) 74:211-20. doi:10.1002/ cyto.b. 20420

10. Tormo N, Solano C, Benet I, Nieto J, de la Cámara R, López J, et al. Reconstitution of CMV pp65 and IE-1-specific IFN- $\gamma \mathrm{CD} 8(+)$ and CD4(+) T-cell responses affording protection from CMV DNAemia following allogeneic hematopoietic SCT. Bone Marrow Transplant (2011) 46:1437-43. doi:10.1038/ bmt.2010.330

receptor, in particular when a high-avidity peptide is used (59); (2) MHC-multimer staining is HLA-specific and peptidespecific. Therefore the whole cell repertoire directed against a pathogen cannot yet be determined using MHC-multimer technology.

\section{CONCLUSION}

T-cell monitoring against specific targets including viruses and fungi is ready to be integrated in the clinical practice. The monitoring of pathogen-specific $\mathrm{T}$ cells may help to define the individual MPE of a patient to develop a certain infections complication and to assess the potential benefit of adoptive T-cell therapy against certain pathogens.

\section{ACKNOWLEDGMENTS}

I appreciate Dr. Julia Fisher and Ms. Elke Baumeister, University of Würzburg, Würzburg, Germany, and Dr. Kohei Tada, National Cancer Center Hospital, Tokyo, Japan for their technical assistance.

11. Boeckh M, Leisenring W, Riddell SR, Bowden RA, Huang ML, Myerson D, et al. Late cytomegalovirus disease and mortality in recipients of allogeneic hematopoietic stem cell transplants: importance of viral load and T-cell immunity. Blood (2003) 101:407-14. doi:10.1182/blood-2002-03-0993

12. Krause H, Hebart H, Jahn G, Muller CA, Einsele H. Screening for CMV-specific $\mathrm{T}$ cell proliferation to identify patients at risk of developing late onset CMV disease. Bone Marrow Transplant (1997) 19:1111-6. doi:10.1038/sj. bmt.1700801

13. Schmitt A, Tonn T, Busch DH, Grigoleit GU, Einsele $H$, Odendahl $\mathrm{M}$, et al. Adoptive transfer and selective reconstitution of streptamer-selected cytomegalovirus-specific CD8+ $\mathrm{T}$ cells leads to virus clearance in patients after allogeneic peripheral blood stem cell transplantation. Transfusion (2011) 51:591-9. doi:10.1111/j.1537-2995.2010. 02940.x

14. Feuchtinger T, Opherk K, Bethge WA, Topp MS, Schuster FR, Weissinger EM, et al. Adoptive transfer of pp65-specific $\mathrm{T}$ cells for the treatment of chemorefractory cytomegalovirus disease or reactivation after haploidentical and matched unrelated stem cell transplantation. Blood (2010) 116:4360-7. doi:10.1182/ blood-2010-01-262089

15. Lindemans CA, Leen AM, Boelens JJ. How I treat adenovirus in hematopoietic stem cell transplant recipients. Blood (2010)
116:5476-85. doi:10.1182/blood2010-04-259291

16. Zandvliet ML, Falkenburg JH, van Liempt E, Veltrop-Duits LA, Lankester AC, Kalpoe JS, et al. Combined CD8+ and CD4+ adenovirus hexon-specific $\mathrm{T}$ cells associated with viral clearance after stem cell transplantation as treatment for adenovirus infection. Haematologica (2010) 95:1943-51. doi:10. 3324/haematol.2010.022947

17. Feuchtinger T, Richard C, Joachim S, Scheible $\mathrm{MH}$, Schumm M, Hamprecht $\mathrm{K}$, et al. Clinical grade generation of hexonspecific $\mathrm{T}$ cells for adoptive T-cell transfer as a treatment of adenovirus infection after allogeneic stem cell transplantation. J Immunother (2008) 31:199-206. doi:10.1097/CJI. 0b013e31815ef862

18. Feuchtinger T, Matthes-Martin S, Richard C, Lion T, Fuhrer $M$, Hamprecht K, et al. Safe adoptive transfer of virus-specific Tcell immunity for the treatment of systemic adenovirus infection after allogeneic stem cell transplantation. $\mathrm{Br} \mathrm{J}$ Haematol (2006) 134:64-76. doi:10.1111/j. 1365-2141.2006.06108.x

19. Annels NE, Kalpoe JS, Bredius RG, Claas EC, Kroes AC, Hislop $\mathrm{AD}$, et al. Management of Epstein-Barr virus (EBV) reactivation after allogeneic stem cell transplantation by simultaneous analysis of EBV DNA load and EBV-specific $\mathrm{T}$ cell reconstitution. Clin Infect Dis (2006) 42:1743-8. doi: $10.1086 / 503838$ 
20. Icheva V, Kayser S, Wolff D, Tuve $\mathrm{S}$, Kyzirakos C, Bethge W, et al. Adoptive transfer of Epstein-Barr virus (EBV) nuclear antigen 1specific $\mathrm{T}$ cells as treatment for EBV reactivation and lymphoproliferative disorders after allogeneic stem-cell transplantation. J Clin Oncol (2013) 31:39-48. doi:10. 1200/JCO.2011.39.8495

21. Moosmann A, Bigalke I, Tischer J, Schirrmann L, Kasten J, Tippmer S, et al. Effective and long-term control of EBV PTLD after transfer of peptide-selected T cells. Blood (2010) 115:2960-70. doi:10.1182/ blood-2009-08-236356

22. Trydzenskaya H, Sattler A, Müller K, Schachtner T, Dang-Heine C, Friedrich $\mathrm{P}$, et al. Novel approach for improved assessment of phenotypic and functional characteristics of BKVspecific T-cell immunity. Transplantation (2011) 92:1269-77. doi: 10.1097/TP.0b013e318234e0e5

23. Blyth E, Clancy L, Simms R, Gaundar S, O'Connell P, Micklethwaite $\mathrm{K}$, et al. $\mathrm{BK}$ virus-specific $\mathrm{T}$ cells for use in cellular therapy show specificity to multiple antigens and polyfunctional cytokine responses. Transplantation (2011) 92:1077-84. doi:10. 1097/TP.0b013e31823328c0

24. Schachtner T, Müller K, Stein M, Diezemann C, Sefrin A, Babel N, et al. BK virus-specific immunity kinetics: a predictor of recovery from polyomavirus $\mathrm{BK}$-associated nephropathy. Am J Transplant (2011) 11:2443-52. doi:10.1111/j. 1600-6143.2011.03693.x

25. Chakera A, Bennett S, Lawrence $\mathrm{S}$, Morteau $\mathrm{O}$, Mason PD, O'Callaghan CA, et al. Antigenspecific $\mathrm{T}$ cell responses to $\mathrm{BK}$ polyomavirus antigens identify functional anti-viral immunity and may help to guide immunosuppression following renal transplantation. Clin Exp Immunol (2011) 165:401-9. doi:10.1111/j. 1365-2249.2011.04429.x

26. Du Pasquier RA, Kuroda MJ, Schmitz JE, Zheng Y, Martin $\mathrm{K}$, Peyerl FW, et al. Low frequency of cytotoxic T lymphocytes against the novel HLA$\mathrm{A}^{\star}$ 0201-restricted JC virus epitope $\mathrm{VP} 1$ (p36) in patients with proven or possible progressive multifocal leukoencephalopathy. J Virol (2003) 77:11918-26. doi:10.1128/ JVI.77.22.11918-11926.2003

27. Du Pasquier RA, Kuroda MJ, Zheng Y, Jean-Jacques J, Letvin NL, Koralnik IJ. A prospective study demonstrates an association between JC virus-specific cytotoxic $\mathrm{T}$ lymphocytes and the early control of progressive multifocal leukoencephalopathy. Brain (2004) 127:1970-8. doi:10.1093/ brain/awh215

28. Leen AM, Bollard CM, Mendizabal AM, Shpall EJ, Szabolcs P, Antin $\mathrm{JH}$, et al. Multicenter study of banked third party virus-specific T-cells to treat severe viral infections after hematopoietic stem cell transplantation. Blood (2013) 121:5113-23. doi:10.1182/blood2013-02-486324

29. Hebart H, Bollinger C, Fisch P, Sarfati J, Meisner C, Baur M, et al. Analysis of T-cell responses to Aspergillus fumigatus antigens in healthy individuals and patients with hematologic malignancies. Blood (2002) 100:4521-8. doi:10. 1182/blood-2002-01-0265

30. Potenza L, Barozzi P, Vallerini D, Bosco R, Quadrelli C, Mediani L, et al. Diagnosis of invasive aspergillosis by tracking Aspergillus-specific $\mathrm{T}$ cells in hematologic patients with pulmonary infiltrates. Leukemia (2007) 21:578-81. doi:10.1038/sj.leu.2404504

31. Potenza L, Barozzi P, Rossi G, Palazzi G, Vallerini D, Riva G, et al. Assessment of Aspergillusspecific $\mathrm{T}$ cells for diagnosis of invasive aspergillosis in a leukemic child with liver lesions mimicking hepatosplenic candidiasis. Clin Vaccine Immunol (2008) 15:1625-8. doi:10.1128/CVI.00198-08

32. Chaudhary N, Staab JF, Marr KA. Healthy human T-cell responses to Aspergillus fumigatus antigens. PLoS One (2010) 5(2):e9036. doi: 10.1371/journal.pone.0009036

33. Wald A, Leisenring W, van Burik JA, Bowden RA. Epidemiology of Aspergillus infections in a large cohort of patients undergoing bone marrow transplantation. J Infect Dis (1997) 175(6):1459-66. doi:10.1086/516480

34. Marr KA, Carter RA, Boeckh M, Martin P, Corey L. Invasive aspergillosis in allogeneic stem cell transplant recipients: changes in epidemiology and risk factors. Blood (2002) 100:4358-66. doi:10. 1182/blood-2002-05-1496

35. Beck O, Koehl U, Tramsen L, Mousset S, Latgé JP, Müller K, et al. Enumeration of functionally active anti-Aspergillus T-cells in human peripheral blood. J Immunol Methods (2008) 335:41-5. doi:10.1016/ j.jim.2008.02.014
36. Perruccio K, Tosti A, Burchielli E, Topini F, Ruggeri L, Carotti A, et al. Transferring functional immune responses to pathogens after haploidentical hematopoietic transplantation. Blood (2005) 106:4397-406. doi:10.1182/blood2005-05- 1775

37. Tramsen L, Koehl U, Tonn T, Latgé JP, Schuster FR, Borkhardt $A$, et al. Clinical-scale generation of human anti-Aspergillus $\mathrm{T}$ cells for adoptive immunotherapy. Bone Marrow Transplant (2009) 43:13-9. doi:10.1038/bmt. 2008.271

38. Beck O, Topp MS, Koehl U, Roilides E, Simitsopoulou M, Hanisch M, et al. Generation of highly purified and functionally active human $\mathrm{TH} 1$ cells against Aspergillus fumigatus. Blood (2006) 107:2562-9. doi:10.1182/blood-2005-04-1660

39. Khanna N, Stuehler C, Conrad B, Lurati S, Krappmann S, Einsele $\mathrm{H}$, et al. Generation of a multipathogen-specific T-cell product for adoptive immunotherapy based on activation-dependent expression of CD154. Blood (2011) 118:1121-31. doi:10.1182/blood2010-12-322610

40. Tramsen L, Schmidt S, Boenig H, Latgé JP, Lass-Flörl C, Roeger $\mathrm{F}$, et al. Clinical-scale generation of multi-specific anti-fungal $\mathrm{T}$ cells targeting Candida, Aspergillus and mucormycetes. Cytotherapy (2013) 15:344-51. doi:10.1016/j. jcyt.2012.11.014

41. Maecker HT, Moon J, Bhatia S, Ghanekar SA, Maino VC, Payne $\mathrm{JK}$, et al. Impact of cryopreservation on tetramer, cytokine flow cytometry, and ELISPOT. BMC Immunol (2005) 6:17. doi:10.1186/ 1471-2172-6-17

42. Britten CM, Gouttefangeas C, Welters MJ, Pawelec G, Koch $\mathrm{S}$, Ottensmeier $\mathrm{C}$, et al. The CIMT-monitoring panel: a two-step approach to harmonize the enumeration of antigen-specific CD8+ $\mathrm{T}$ lymphocytes by structural and functional assays. Cancer Immunol Immunother (2008) 57:289-302. doi:10.1007/s00262007-0378-0

43. Augustine JJ, Hricik DE. Tcell immune monitoring by the ELISPOT assay for interferon gamma. Clin Chim Acta (2012) 413:1359-63. doi:10.1016/j.cca.2012.03.006

44. Hehmann PV, Zhang W. Unique strengths of ELISPOT for $\mathrm{T}$ cell diagnostics. Methods $\mathrm{Mol}$ Biol (2012) 792:3-23. doi:10.1007/9781-61779-325-7_1

45. Shafer-Weaver K, Sayers T, Strobl S, Derby E, Ulderich T, Baseler M, et al. The granzyme B ELISPOT assay: an alternative to the ${ }^{51} \mathrm{Cr}$ release assay for monitoring cellmediated cytotoxicity. J Transl Med (2003) 1:14. doi:10.1186/ 1479-5876-1-14

46. Rininsland FH, Helms T, Asaad RJ, Boehm BO, Tary-Lehmann M. Granzyme B ELISPOT assay for ex vivo measurements of $\mathrm{T}$ cell immunity. J Immunol Methods (2000) 240:143-55. doi:10.1016/ S0022-1759(00)00191-5

47. Ahlborg N, Axelsson B. Dual- and triple-color fluorospot. Methods Mol Biol (2012) 792:77-85. doi:10. 1007/978-1-61779-325-7_6

48. Gazagne A, Claret E, Wijdenes J, Yssel H, Bousquet F, Levy $\mathrm{E}$, et al. A fluorospot assay to detect single $\mathrm{T}$ lymphocytes simultaneously producing multiple cytokines. J Immunol Methods (2003) 283:91-8. doi:10.1016/ j.jim.2003.08.013

49. Wang M, Tang ST, Lund O, Dziegiel $\mathrm{MH}$, Buus S, Claesson $\mathrm{MH}$. High-affinity human leucocyte antigen class I binding variola-derived peptides induce CD4 $\mathrm{T}$ cell responses more than 30 years post-vaccinia virus vaccination. Clin Exp Immunol (2009) 155:441-6. doi:10.1111/j. 1365-2249.2008.03856.x

50. Wang $M$, Larsen MV, Nielsen M, Harndahl M, Justesen S, Dziegiel $\mathrm{MH}$, et al. HLA class I binding 9mer peptides from influenza A virus induce CD4 T cell responses. PLoS One (2010) 5:e10533. doi:10.1371/journal pone. 0010533

51. Nomura L, Maino VC, Maecker HT. Standardization and optimization of multiparameter intracellular cytokine staining. Cytometry $A$ (2008) 73:984-91. doi:10. 1002/cyto.a.20602

52. Lamoreaux L, Roederer M, Koup R. Intracellular cytokine optimization and standard operating procedure. Nat Protoc (2006) 1:1507-16. doi:10.1038/nprot.2006.268

53. Appay V, van Lier RA, Sallusto F, Roederer M. Phenotype and function of human $\mathrm{T}$ lymphocyte subsets: consensus and issues. Cytometry A (2008) 73:975-83. doi:10.1002/cyto.a.20643

54. Chattopadhyay PK, Melenhorst JJ, Ladell K, Gostick E, 
Scheinberg P, Barrett AJ, et al. Techniques to improve the direct ex vivo detection of low frequency antigen-specific CD8+ $\mathrm{T}$ cells with peptide-major histocompatibility complex class I tetramers. Cytometry A (2008) 73:1001-9. doi:10.1002/cyto.a.20642

55. Neudorfer J, Schmidt B, Huster KM, Anderl F, Schiemann M, Holzapfel G, et al. Reversible HLA multimers (streptamers) for the isolation of human cytotoxic $\mathrm{T}$ lymphocytes functionally active against tumor- and virus-derived antigens. J Immunol Methods (2007) 320:119-31. doi: 10.1016/j.jim.2007.01.001

56. Engstrand M, Lidehall AK, Totterman TH, Herrman B, Eriksson BM, Korsgren O.
Cellular responses to cytomegalovirus in immunosuppressed patients: circulating CD8+ $\mathrm{T}$ cells recognizing CMVpp65 are present but display functional impairment. Clin Exp Immunol (2003) 132:96-104. doi:10.1046/j. 1365-2249.2003.02098.x

57. Mattes FM, Vargas A, Kopycinski J, Hainsworth EG, Sweny P, Nebbia G, et al. Functional impairment of cytomegalovirus specific CD8 $\mathrm{T}$ cells predicts high-level replication after renal transplantation. Am J Transplant (2008) 8:990-9. doi:10.1111/j.1600-6143. 2008.02191.x

58. Yang R, Xia T, Xu G, Li Z, Ying Z, $\mathrm{Xu} \mathrm{X}$. Human cytomegalovirus specific CD8(+) T lymphocytes display interferon-gamma secretion impairment in kidney transplant recipients with pp65 antigenemia. Transplant Proc (2008) 40:3500-4. doi:10.1016/j. transproceed.2008.03.176

59. Appay V, Nixon DF, Donahoe SM, Gillespie GM, Dong T, King A, et al. HIV-specific CD8(+) T cells produce antiviral cytokines but are impaired in cytolytic function. $J$ Exp Med (2000) 192:63-75. doi:10. 1084/jem.192.1.63

Conflict of Interest Statement: The authors declare that the research was conducted in the absence of any commercial or financial relationships that could be construed as a potential conflict of interest.

Received: 07 August 2013; accepted: 29 August 2013; published online: 17 September 2013.
Citation: Fuji S, Kapp $M$ and Einsele $H$ (2013) Monitoring of pathogen-specific $T$-cell immune reconstitution after allogeneic hematopoietic stem cell transplantation. Front. Immunol. 4:276. doi: 10.3389/fimmu.2013.00276

This article was submitted to Alloimmunity and Transplantation, a section of the journal Frontiers in Immunology.

Copyright $\odot 2013$ Fuji, Kapp and Einsele. This is an open-access article distributed under the terms of the Creative Commons Attribution License (CC BY).

The use, distribution or reproduction in other forums is permitted, provided the original author(s) or licensor are credited and that the original publication in this journal is cited, in accordance with accepted academic practice. No use, distribution or reproduction is permitted which does not comply with these terms. 